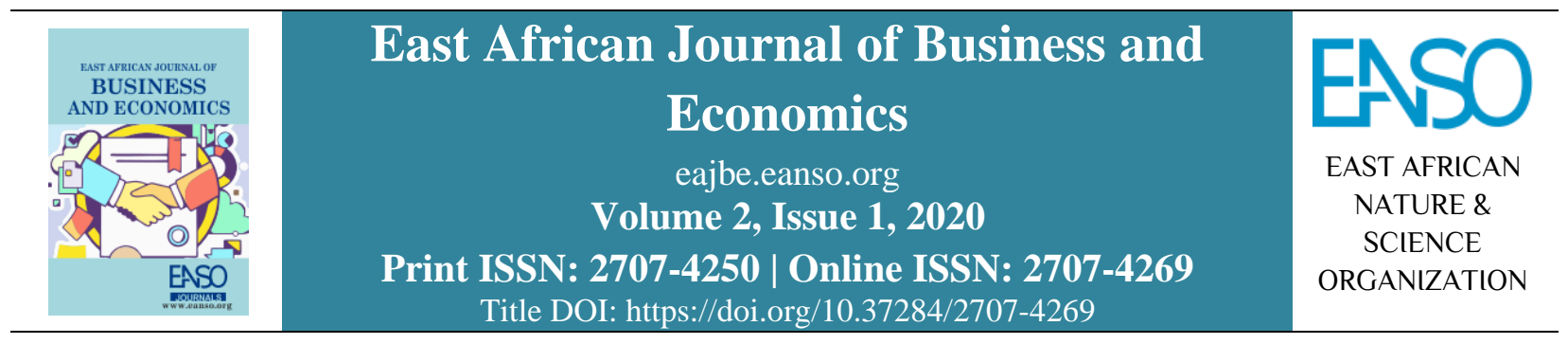

Original Article

\title{
E-HRM and Motivation: A Case of Manufacturing Companies in Tanzania
}

\author{
Namrata Shah ${ }^{*}$, Francis Michael, $P h D^{l} \&$ Henry Chalu, $P h D^{1}$ \\ ${ }^{1}$ University of Dar es Salaam Business School (UDBS), P. O. Box 35046, Dar es Salaam, Tanzania. \\ *Correspondence email: namrata.tolia9@gmail.com.
}

Article DOI: https://doi.org/10.37284/eajbe.2.1.241

\begin{abstract}
Date Published: ABSTRACT
26 November 2020 Organisations are encountering more challenges than ever, owing to the speedy and dynamic development of e-business. This has headed companies to pursue

Keywords: better opportunities to run HR operations more effectively by adopting technology in the human resource department. Today, top leaders entirely Human Resource comprehend the power of information technology (IT) tools for the attainment Management, of business targets. Thus, the purpose of this paper is to assess the current and E-HRM, emergent concepts of the Electronic Human Resource Management (E-HRM) Motivation, in Tanzanian organisations and study how it characters employees' motivation. Manufacturing A survey was carried out; PLS-SEM technique was used to examine the effects Company of E-HRM on motivation. The paper outcomes suggested an apparent influence of electronic-human resource management on motivation. We have inspected research done on E-HRM and have developed a model of the factors which directed to HR electronic use and motivation study. This paper gives a brief outline of the prospects of E-HRM and Motivation in Tanzanian firms.
\end{abstract}

\section{APA CITATION}

Shah, N., Michael, F., \& Chalu, H. (2020). E-HRM and Motivation: A Case of Manufacturing Company in Tanzania. East African Journal of Business and Economics, 2(1), 53-71. https://doi.org/10.37284/eajbe.2.1.241

\section{CHICAGO CITATION}

Shah, Namrata, Francis Michael, and Henry Chalu. 2020. "E-HRM and Motivation: A Case of Manufacturing Company in Tanzania". East African Journal of Business and Economics 2 (1), 53-71. https://doi.org/10.37284/eajbe.2.1.241.

\section{HARVARD CITATION}

Shah, N., Michael, F. and Chalu, H. (2020) "E-HRM and Motivation: A Case of Manufacturing Company in Tanzania", East African Journal of Business and Economics, 2(1), pp. 53-71. doi: 10.37284/eajbe.2.1.241.

\section{IEEE CITATION}

N. Shah, F. Michael, and H. Chalu, "E-HRM and Motivation: A Case of Manufacturing Company in Tanzania", EAJBE, vol. 2 , no. 1, pp. 53-71, Nov. 2020. 
East African Journal of Business and Economics, Volume 2, Issue 1, 2020

Article DOI: https://doi.org/10.37284/eajbe.2.1.241

MLA CITATION

Shah, Namrata, Francis Michael, and Henry Chalu. "E-HRM and Motivation: A Case of Manufacturing Company in Tanzania". East African Journal of Business and Economics, Vol. 2, no. 1, Nov. 2020, pp. 53-71, doi:10.37284/eajbe.2.1.241

\section{INTRODUCTION}

Information technology empowers the managers and employees to execute trifling human resource (HR) functions, thereby alleviating the HR miscellaneous functions and concentrating more on the core responsibilities of strategic components. Such strategy supports the organisation to curtail Human Resource staffing levels as the department is effectively utilised. Predictably E-HRM creates a deep-rooted impact on the business and its employees (Bulmash, 2013). E-HRM allows managers and employees to do numerous of the reporting-kind actions which were earlier done by HR professionals (Martin, 200; Ruta, 2005). At the ease of their workspace and time; managers today do appraisals, device employee costs, produce HR information (turnover, absenteeism), course training requirements and supervise skill management; which makes them lean towards using E-HRM (Poisat and Mey, 2017).

The "e" revolution (e-mail, e-commerce, etc.) where the letter "e" symbolises the execution and application of the action defined by the usage of Internet technology has similarly given birth to EHRM (Strohmeier, 2007). Fundamental groundbreaking changes are noticeable by this revolutionary approach to HRM (Strohmeier, 2007). The explanation of E-HRM that is most used nowadays is that of Strohmeier (2007), which says "E-HRM is the (planning, implementation and) application of information technology for both networking and supporting at least two individual or collective actors in their shared performing of HR activities." Performance enhancements within the HR body, cost reductions, return on investments and improved outcome are the four most significant facts to support E-HRM investments as per a survey conducted by Watson Wyatt (2002).
Many developing nations still lag in growth and utilisation of E-HRM system, in spite of knowing E-HRM outcomes (Walinda, 2013). The push for the institution of E-HRM system in developing countries is determined from the proclamation of policies, legislative and regulatory framework as well as infrastructure development (Mutula, 2010). The E-HRM system in developing nations is still at its initial stages. It is noted that all African countries do not have full internet access and where they do, they may not have suitable information. For the determination of achieving improved facilities to Tanzanian citizens through its organisations since the 1990s, there are sequences of actions for renovating itself into becoming further efficient, effective and customer-oriented. These actions have put in place the basics for what is now known as E-HRM (International Records Management Trust, 2007). In Tanzania, data on the role of EHRM on Human Resource Management is scarce (International Records Management Trust, 2007).

Operational, relational, and transformational are the forms of e-HRM recognised by existing literature. Lepak and Snell (1998) developed these divisions. Operational e-HRM involves the elementary HR actions in the administrative capacity, which include compensation. The next area, relational eHRM, involves further developed HR actions which include recruitment; whereas HR actions which include knowledge management, is the last area of e-HRM which is termed as transformational (Ruel, Bondarouk and Looise, 2004). Likewise, an action stimulating people to act properly is called motivation. The human resource system is necessary if an enterprise is going to improve employee's skills and employees' motivation (Delaney and Huselid, 1996; Teo et al., 1999; Liaw and Huang, 2003).

This paper utilises Ulrich's HR role model theory and Vrooms Motivational Theory as a theoretical 
foundation to study E-HRM measures and Motivational measures (Davis, 1989). Ulrich's HR role model offers a framework for the decision of employees on how and when they will use E-HRM and Vroom's Motivational model offers a basis to see how it affects employees. Largely, businesses incorporate technology in their human resource management to increase profitability and reduce costs. However, this might not be willingly attained in some industries where HR innovation is not reflected as a new force for success but rather a pitfall for employees. How usage of E-HRM will affect motivation needs to be examined (Hafez, 2011). It is hence interesting to ascertain the outcomes of E-HRM; the problem to be researched is to examine if E-HRM brings positive or negative outcomes to its users. In this digital age, the issues that will be researched in this paper are the effect of E-HRM on Motivation.

This study recognises the effect of E-HRM in Tanzanian organisations and describes the effect of E-HRM and the influence it has on motivation. Employee's behaviours in the direction of E-HRM have examined in the light of Ulrich's HR role model as well as the relationship between subjective norms and the employees' willingness to accept such E-HRM (Venkatesh and Davis, 1996). Outcomes of the paper are supposed to express the impact of E-HRM on employee's motivation.

Developing, overseeing, and coordinating actions like compensation, recruitment, knowledge management is the primary responsibility of EHRM. Managerial and employee support or participation is an affirmative input is encouraged since participation indicates a commitment to the program and its objectives. Compensation, recruitment, knowledge management today also emphasises objective means of measurement. For the organisation in general and HRM in particular, compensation, recruitment, knowledge management operates as a critical system. Even if the compensation, recruitment, and knowledge management processes are carefully designed, its implementation may fail due to lack of management support (Anderson, 1997).

\section{LITERATURE REVIEW}

The invention and innovation of technology have enabled the creation of unique tools and techniques, making various endeavours possible. A profound effect on the rapid development of e-business and e-management on organisations has altered human resource tradition and diversified challenges in an effort to meet new e-business trends. As such Human Resource plays a major role in pulling and pooling strategies for business success. The role of Human resource should be more flexible within the new form of web/tech-business thereby making the use of information technology imminent for ebusiness success simultaneously enticing and retaining employees (Parry, 2011). The organisations in the mid-1990s increasingly laid the foundation for E-HRM, web-based HRM and digital HRM. The agile advancement of technology has introduced new areas in the organisations where the presence of human resource consultants has been vindicated considerably, thereby opening doors for E-HRM with the intensity of constant increase in application worldwide.

Mutula's (2008) quantitative survey compared ICT position of sub-Saharan African nations with established and developing nations. Besides, investigation of universal e-services, digital prospect and information society directories were exercised. He realised that extensive inequalities in E-HRM method occur within provincial transacting areas in sub-Saharan Africa with Southern Africa being the far way forward of East and West African countries. Numerous hurdles comprising legal, infrastructure, policy and skill factors are recognised as restricting the prospects for subSaharan Africa to shift government services to virtual systems (Nkohkwo \& Islam, 2013). In his research, Mutula (2010) suggested that Africa should invest more in infrastructure and develop a governmental strategy that meritoriously contends 
with established and developing countries not only in e-services but even in the global economy. Tanzania identical to any African nation is struggling to invest in infrastructure and but also has a favourable atmosphere for legislative and policy reforms based on the meritorious application of ICTs mainly in E-HRM structure (Walinda, 2013).

\section{Theoretical Foundation}

There are several motivational theories voiced in the literature over the years regarding technological adoptions. Even so, motivational theories posit that motivation involves a desire to act, the ability to act, and having an objective (Ramlall, 2004). 'Expectancy theory embraces that people are motivated to behave in ways that produce desired combinations of expected outcomes' (Krietner \& Kinicki, 1998).

Vroom's Expectancy Theory attempts to make it clear that motivated behaviour is goal-oriented. He contends that people tend to act in a hedonistic way (Vroom, 1964) selecting the actions that will get the highest subjective utility. Fundamentally, the expectancy theory debates that the strong point of inclination to act in a certain way rests on the power of an expectation that the act will be followed by a given result and on the attractiveness of that result to the individual (Robbins, 1993). As a result, the behaviour could be oriented towards anticipated and individualised goals. Vroom's theory states that the 'choices made by a person among alternative courses of action are lawfully related to psychological events occurring contemporaneously with the behaviour' (Vroom, 1964). This paper presents the expectancy theory as an integrative motivational approach in E-HRM use.

The expectancy theory was chosen among other motivational theories to make available the guidelines for our analysis in this paper. The reasons for choosing this theory is that many features of other motivational theories can be housed within the broader framework of expectancy theory, thus offering it with a special power of becoming an integrating motivational approach.

Ulrich (1997) labels different roles of HR professionals in the HR function performance. Human Resources departments are important in organisations in part because of how they focus on the people in an organisation, including employees, managers, board members, and more. Fittingly, David Ulrich's HR Model does not build a Human Resources department around function first, but rather around roles. Ulrich (1997) expresses "strategic partners" as the HR specialists that operate along with uppermost officials and chiefs to make aggressive business tactics and to outline apt HR approaches, policies, routines and job to meet business strategies and objectives. The strategic partner includes Knowledge Management (Transformational) function. The second part "Administrative experts" are individuals that must make HR work more efficient and effective. Administrative expert includes Compensation (Operational) functions. "Employee champions" advocates, the first action HR professionals must perform is to comprehend and discover the demand of employees. "Change agents" are the HR experts that upkeep the business renovations and bring about organisation modifications. Change agent includes Recruitment (Relational) functions. Moreover, the HR role by Ulrich (1997) is undoubtedly the best in the HR roles works and it is broadly referred to in HR literature (Lawler and Mohran, 2003).

Furthermore, the dimension of Ulrich's HR roles has been verified to have an authentic and dependable measure (Voermans \& Veldhoven, 2007; Conner \& Ulrich, 1996; Yusliza \& Hasliza, 2009). The researchers assumed that if these compensations (administrative expert), recruitment (change agent) and knowledge management (strategic partner) functions are carried out using eHRM, then it will affect HR motivation. Vroom's 
motivation theory supplemented by Ulrich's HR roles model was used since one theory is not sufficient to explain all the variables pertaining to HR roles and motivation related variables.

\section{CONCEPTUAL FRAMEWORK AND HYPOTHESIS DEVELOPMENT}

The Conceptual Framework indicates that e-HRM practices influence employees' motivation. In detail, the framework shows that e-recruitment, ecompensation and e-knowledge management influence motivation (effort, performance and outcome). The study examined the influence of EHRM on employees' motivation. Three hypotheses were made:

\section{E-Recruitment and Motivation}

The rapid development of modern information and communication technologies in the past few years has greatly increased the amount of information available in all levels of the social and business environment (Campbell et al., 2012). People have been steadily turning to the web to improve their knowledge and skills (Ho et al., 2010) as well as for career development (Jansen et al., 2005). What is more, job seekers are increasingly using Web services like LinkedIn and job search sites (Bizer and Rainer, 2005). On the other hand, many companies use online knowledge management systems to hire employees, exploiting the advantages of the world wide web. These are erecruitment systems and automate the process of publishing positions and receiving CVs.

Campbell et al. (2012) focused on the influence of recruitment on motivation in the health sector in rural Australia and his findings show a positive relationship between recruitment and motivation. Similarly, a study by Matolo et al. (2019) based on Vroom's motivational theory found there was a significant positive relationship between recruitment and selection and employee performance which is a motivational factor. Mencken and Winfield (1998) explored the advantages and disadvantages of informal and formal recruiting practices in external labour markets. The authors found that performance quality was a strong motivator than the cost of informal recruiting. The findings from their regression analysis also demonstrated that the quality of applicants was more salient for hiring managers in the sector. There is an argument that internet knowhow has turned into a most important instrument for recruiting and selecting workforces (Cappelli \& Neumark, 2001). Recruiting turned into one of the very fruitful functions of the web due to internet technology advent and the way it positively influences performance and employee commitment (Keating and Harrington, 2002). Amongst the many advantages of recruitment, there is very little knowledge of its effect on motivation.

People typically make an effort and act to meet goals like performance and outcome, which means that motivation, is considered a goal-directed drive that rarely occurs in a void. However, some factors can obstruct motivation and work performance which includes employees' capabilities and determination to get work done in spite of difficulties. For example, when experiencing poor employee performance, the business should determine whether the inefficiency of the individual is caused by inconsistent motivation initiatives, employee insufficiencies or deficiencies, or poor rewards offered (Mathis \& Jackson, 2010). Some studies such as Li et al. (2006) have the opined that rewards, including pay increases, promotion, and internal recruitment have a negative effect on motivation. Due to these different findings from various studies, it becomes necessary to find the effect of E-Recruitment on motivation. According to Vroom (1964), motivation is a product of the individual's expectancy that a certain effort will lead to the intended performance, the instrumentality of this performance to achieving a certain result. This paper is focused on looking at the effect of recruitment (E-HRM) has on motivation. To be able to make meaningful 
inferences, the relation between E-Recruitment and Motivation needs to be tested statistically in Tanzanian organisation. Therefore, this study assumed that:

\section{$\boldsymbol{H}_{1}$ : E-Recruitment has a significant relationship with HR motivation.}

\section{E-Compensation and Motivation}

Vroom (1964) articulates that individual makes choices based on estimates of how well the expected results of a given behaviour are going to match up with or eventually lead to the desired results. Motivation is gained by need satisfaction which can be stimulated by monetary rewards (Frey, 1997). In the model of the HR role by Ulrich (1997), the administrative expert relates to procedure proficiency that includes individuals and maximum time this function consumes the HR tasks. Researchers agree that operational e-HRM includes compensation (Khatoon, 2012).

Igalens et al. (1999) in their study assessing the relationships between compensation package, work motivation and job satisfaction in France, applied the theoretical framework based on expectancy theory. The study examined how the elements of total compensation might influence work motivation and job satisfaction. Their study findings show a positive effect of compensation on motivation. On the other hand, Khan et al. (2012) in their study used Vroom's Expectancy theory to measure motivation in their research. The result showed that employees are not motivated by compensation.

Compensation is a result which is utmost desired by employees. Compensation via E-HRM may well be termed as an internet-centred application that assists managers to model, manage, and impart compensation systems more meritoriously (Duhlebohn \& Marler, 2005). Compensation means are very useful for planning and managing compensation procedures in a competitive and vibrant atmosphere (Dulebohn \& Marler, 2005;
Stone et al., 2009). It has been argued that compensation systems decrease costs, errors, and the time it takes to implement compensation planning and increases performance and outcome (Dulebohn \& Marler, 2005). In support of these arguments, research focused primarily on the benefits of implementing compensation systems (Brink \& McDonnell, 2003; Dulebohn \& Marler, 2005). Another academic research by Mauldin (2003) found that the use of expert systems in compensation planning (i.e., developing performance contingent incentives) increased decision accuracy which encourages employees to make a smart effort for improved performance. Although the results of industry research support the benefits of compensation systems, objective academic research is needed to understand the degree to which these systems help in motivation, therefore, from the above discussion this study assumed that:

\section{$\boldsymbol{H}_{2}$ : E-Compensation has a significant impact on motivation.}

\section{E-Knowledge Management and Motivation}

From the knowledge-based perspective, the most important means of production are intangible. The knowledge-based view puts great emphasis on human capital; that is the skills, knowledge, competences, attitudes, and motivation of the people working for an organisation, and the way that they use these skills for the benefit of the organisation (Shultz \& Slevin, 1975; Crook et al., 2011). Knowledge is generally accepted as an acute organisational resource regardless of sort of business (Stewart, 1997; Sveiby, 1997). Knowledge Management pursues to influence the organisation's proficiency, employee performance and outcome; and knowhow to enhance value to the business, employing a certain type of technological support system (Davenport and Prusak, 1998). Knowledge management refers to identifying and leveraging the collective knowledge in an organisation to help the organisation compete. 
This is an economy where the value of knowledge as input and output is growing; knowledge is a key ingredient of what is bought and sold (both explicitly and implicitly). Knowledge resources are rising in importance relative to traditionally recognised resources. Knowledge management is concerned with making the right knowledge available to the right processors (human or computer) at the right times in the right presentations for the right cost to have the desired effect that favours the organisational goals (Holsapple \& Joshi, 1999).

Kianto et al. (2016) in their study the impact of knowledge management on job satisfaction in south-eastern Finland used the Vrooms motivational theory. PLS-SEM of SmartPLS was used for analyses. Their study results showed positive influence between knowledge management and job satisfaction; however, they overlooked the fact that job satisfaction leads to motivation and hence the need for this study. Another study by Khatoon et al. (2013) found out that knowledge management positively impacts organisational rewards. However, their study failed to look at motivation as organisational rewards in turn lead to motivation. In contrast, Alter (2006) in his demonstrated that knowledge management directly reflects unethical motives which affect individual performance and outcome within an organisation. These may have a negative effect on overall motivation; however, the topic of motivation was overlooked in their study. From the above discussion, E-Knowledge management influence on the motivation is vague in its outcome; hence this study will be guided by the assumption that:

$\boldsymbol{H}_{3}$ : E-Knowledge management has a significant relationship with motivation.

Figure 1: Conceptual Framework on the relationship between E-HRM and Motivation

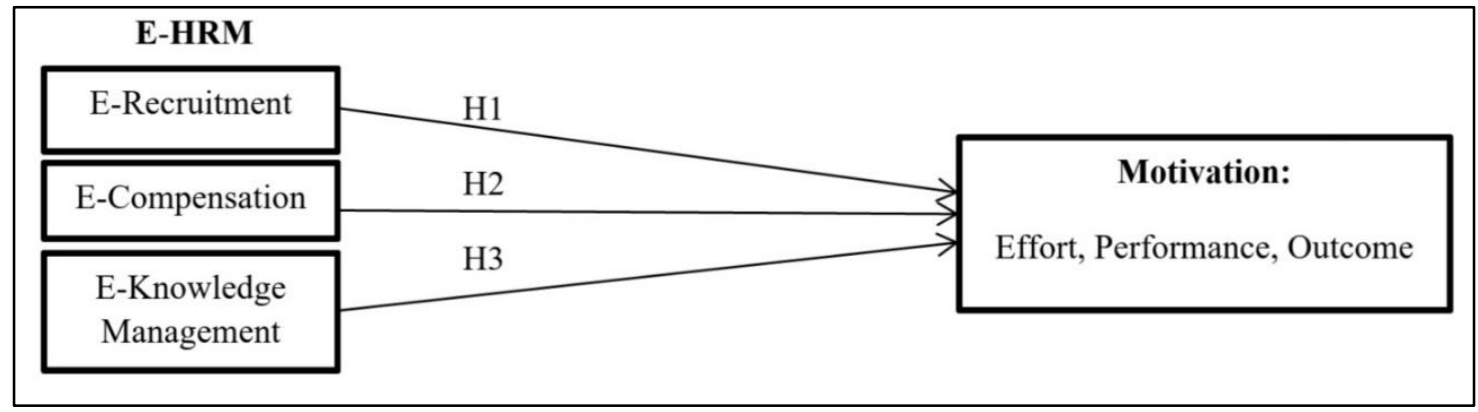

Source: Developed from the theoretical and empirical review (Researcher 2020)

\section{RESEARCH METHODOLOGY}

\section{Research Philosophy}

Research philosophy is deemed as an essential aspect of research methodology as it strengthens the choices of research strategies and methods (Mertens, 2014). The most commonly used philosophies are positivism. Positivism emphasises mainly on the reality of the facts (Yanow, 2015). It is widely used in studies concerning quantitative study methods. The researchers adopted a positivism approach as it is found to be most suitable to provide valuable results to the study in regards to the research objectives. It is asserted that positivism practices prevailing theory to develop hypothesis; after which the hypotheses are tested and confirmed or negated through data (Saunders, Lewis and Thornhill, 2009). This is for the reason that theories were used to develop a hypothesis. Cause and effect laws were put into effect. Relations amongst variables were statistically assessed where the result of the study was generalised (Bhattacherjee, 2012). These components assist in deducing the relationship 
between the variables and collecting the information and testing the hypotheses on this basis. The approach to the study was deductive. According to Wilson (2009), deductive approach is concerned with developing a hypothesis based on existing theory and then designing a research strategy to test the hypothesis.

\section{Research Design}

This type of reasoning approach is related to the research hypotheses that are tested by following the observation tests, after which it gets confirmed or rejected (Blumberg, Cooper and Schindler, 2011). The study adopted a deductive approach as it provides conclusive results. For the reason that it has the attributes related to the deductive approach which accommodates the explanatory research that ascertains the causal associations amongst variables, this study will use Survey research design. It likewise permits the gathering of quantitative data that can be examined quantitatively by means of inferential statistics (Saunders et al., 2009). The survey strategy is apt for gathering statistics regarding a population where subjects are randomly sampled and the findings are generalised making it economical in terms of researcher's time, as survey questionnaires are used to collect data that will save the effort and cost (Bhattacherjee, 2012; Orodho, 2003).

\section{Population and Sampling}

The population of this study was manufacturing organisations in Tanzania. The sampling frame for the study was employees at manufacturing organisations in Tanzania. As per researchers' knowledge, no previous study has done a study in this set up on this area. The researcher chooses the organisation with the established HR department. The unit of analysis was individual manufacturing organisation, and the unit of inquiry was employees at the manufacturing organisation.

According to Saunders et al. (2003), the best research method to use for a study depends on the studies research problem. Descriptive research is adopted in this paper to enable obtaining of data which describes characteristics of the topic of research interest (Hair et al., 2010). It is used for describing various factors under study. The sample consisted of 30 staff members selected randomly. Primary and secondary data were considered. The primary data was collected through the questionnaire comprising of 21 questions starting with the questions regarding age, gender; in addition to, Likert scale questions, while secondary data consist of results from the literature survey.

\section{Data Collection}

Data were collected by the use of a questionnaire that is 5-point Likert scale embraced from the intellectuals that developed the survey instrument (Armstrong, 1987). The survey questionnaire is believed to be suitable in this study as they will facilitate generalisation of the attributes of a large and scattered population from a small group of individuals (Babbie, 1998). The questionnaire was based on the questionnaire used by Khatoon (2012) for measuring the effect of E-HRM. The response was required on five-point Likert scales (endpoints: $1=$ Strongly disagree, $5=$ Strongly agree). Data was acquired through a personally administered questionnaire.

\section{Data Analysis}

As per the data collected, data was analysed using descriptive statistics and Partial Least Squares Structural Equation Modelling (PLS-SEM) assisted with SmartPLS version 3 (Hair et al., 2017). It is used to analyse the relationship of E-HRM and motivation. Data analysis involved factor analysis in confirming the study variables (Yong and Pearce, 2013). The reason for the choice of PLS is that no assumptions are made for variables distribution while ensuring optimal prediction accuracy. PLSSEM could analyse the complex model with the small sample size. It could run for the small sample size even below 50. PLS can be used with fewer 
indicator variables ( 1 or 2 ) per construct. PLS-SEM is also useful if the research model is complex and small samples (Hair et al., 2010).

\section{Reliability and Validity}

In the paper, the researcher has used the quantitative study. The questionnaire was based on the questionnaire used by Khatoon (2012) for measuring the effect of E-HRM. The reason for selecting this questionnaire is that it was used to study the effect of similar variables as in the present study and was well tested on reliability and validity scales and other measures. Studies show that there does not seem to be a consistent opinion on the value of Cronbach's alpha for reliability analysis. Internal consistency of 0.50 and above is considered as a good one (Bowling, 1997), whereas, an alpha of 0.70 or above is considered satisfactory by Howitt and Cramer (2003). In this study, Cronbach's alpha with a benchmark of 0.50 or greater was considered acceptable for checking the reliability of multi-item scales. According to
Khatoon (2012), alpha for these constructs was above 0.7 , which is acceptable.

\section{STUDY FINDINGS}

\section{Profile of the Respondents}

Demographics are shown in a demographics' frequency table (Table 1). The demographics were not used in the present study to find out their relationship with motivation. The objective of Table 1 is to show the composition of respondents to have a better understanding of their response and results for the present study. Majority of the respondents are male and the majority had an experience of less than 10 in their respective organisations. Majority of the respondents have good IT Skills which at present has become a norm to be working. The age of the respondents is an important demographic in the present study as having a higher aged increase work-technology conflict. Majority of the respondents are between 18 to 30 years.

Table 1: Demographic Profile of the Respondents

\begin{tabular}{llll}
\hline Description & & Frequency & Per cent \\
\hline \multirow{2}{*}{ Gender } & Male & 16 & 53.3 \\
& Female & 14 & 46.7 \\
\hline \multirow{3}{*}{ Age } & 18 to 30 years & 30 & 50.8 \\
& 31 to 45 years & 12 & 40.0 \\
& 46 years and above & 12 & 40.0 \\
\multirow{3}{*}{ Tenure } & 0 to 10 years & 24 & 80.0 \\
& 11 to 20 years & 0 & 0 \\
& 21 years and above & 6 & 20.0 \\
\multirow{3}{*}{ IT Skill } & Good & 30 & 100.0 \\
& Average & 0 & 0 \\
& Not Good & 0 & 0 \\
\hline
\end{tabular}

\section{Correlation Analysis}

The Confirmatory Factor Analysis was conducted to determine whether the theoretical specifications would best fit the data. After the analysis was done and the number of items in each variable was confirmed, the overall measurement model which includes the confirmed items was performed. The test was performed and found that all the standardised regression weights reported in the CFA output were above recommended cut-off point 0.50 (Kline, 2010). Therefore, the model in this study was considered to be good as they meet accepted cut off point. Table 2 shows the 
correlation matrix indicates that E-HRM is strongly correlated with motivation in Tanzanian organisations $(0.603, p<.05)$ which is supported by Khatoon (2012). Hence the E-HRM (compensation, recruitment and knowledge management) has a significant effect on motivation (effort, performance and outcome) in Tanzanian private organisations. The broad objective was set to examine the effect of E-HRM on Motivation. The results indicate that the objective is positively supported as motivation is influenced by E-HRM by $60.3 \%$.

Table 2: Correlational Matrix

\section{Correlation Matrix}

\begin{tabular}{lllll} 
& HR Efficiency & Relational & Operational & Transformational \\
\hline HR Efficiency & 1 & $0.667^{*}$ & 0.609 & $0.663^{*}$ \\
Relational & $0.667^{*}$ & 1 & 0.613 & 0.595 \\
Operational & 0.609 & 0.613 & 1 & 0.538 \\
Transformational & $0.663^{*}$ & 0.595 & 0.538 & 1 \\
\hline
\end{tabular}

${ }^{*}$ Correlation is significant at the 0.05 level (2-tailed), $n=30$.

The calculation of correlation yield coefficient that varies between 0 and 1; 0 mean there is no correlation; therefore, no internal consistency and 1 means perfect correlation, therefore complete internal consistency. The usually accepted level is 0.5 and above (Creswell, 2012). The correlation matrix was used to verify the existence of a relationship between the independent variable, i.e. E-HRM and the dependent variable motivation.

\section{Testing of Hypotheses}

PLS-SEM was used to study the nature and magnitude of the relationship between the dependent and independent variable (Table 3). The PLS-SEM was conducted on the model using SmartPLS to test the hypotheses formulated. The full model is reflected and the hypotheses to be tested relates to the pattern of the causal structure linking several variables in the study. The hypothesised research model was suitable with observed data. All the hypothesised paths are supposed to be significant at p-value less than or equal to 0.01 so as to be supported; otherwise, the hypothesis will be not supported by the model. The evaluation of the model shows relationships. In total, three hypotheses were tested between the predictors and the criterion variables. The direct path relationship reflects the direct effect of the latent variables on the dependent variable. In SmartPLS, the relationships between constructs can be determined by examining their path coefficients and related $\mathrm{T}$-statistics via the bootstrapping procedure.

Table 3: Testing of Hypotheses

\begin{tabular}{llllllll}
\hline Hypothesis & $\mathbf{R}^{2}$ & Relationship & Mean & Std Dev & T-Values & P-Values & Hypothesis \\
\hline H1 & & $\begin{array}{l}\text { Recruitment -> Effort, } \\
\text { Performance and } \\
\text { Outcome }\end{array}$ & 0.559 & 0.083 & 6.458 & 0.000 & Supported \\
\hline $\mathbf{H 2}$ & $\begin{array}{l}\text { Compensation -> } \\
\text { Effort, Performance } \\
\text { and Outcome }\end{array}$ & 0.554 & 0.107 & 5.111 & 0.000 & Supported \\
\hline
\end{tabular}




\begin{tabular}{|c|c|c|c|c|c|c|}
\hline Hypothesis $\mathbf{R}^{2}$ & Relationship & Mean & Std Dev & T-Values & P-Values & Hypothesis \\
\hline H3 & $\begin{array}{l}\text { Knowledge } \\
\text { management -> Effort, } \\
\text { Performance and } \\
\text { Outcome }\end{array}$ & 0.648 & 0.111 & 5.699 & 0.000 & Supported \\
\hline
\end{tabular}

**p-value less than or equal to 0.01, Results are significant with 1 tail where: $T$ values $>2.33$

In the case of inferential results, Table 3 provides analysis results of the model. E-HRM is significant at the level of significance. The $\mathrm{R}^{2}$ of the model is $36.4 \%$, which means that E-HRM (compensation, recruitment and knowledge management) can explain the $36.4 \%$ changes in the motivation (effort, performance and outcome) in the organisations of Tanzania, which supports the broad objective of this study. Adjusted $\mathrm{R}^{2}$ of the model is $34.1 \%$ in this study. So the researchers found E-HRM is significantly important. If E-HRM is properly implemented by the organisations in Tanzania, in return, they can get multiple benefits.

\section{E-Recruitment and Motivation}

The first hypothesis of this study was that ERecruitment has a relationship with motivation. This proposed to examine the extent to which ERecruitment influences motivation. The overall descriptive analysis shows that there is a strong positive relationship between recruitment and effort, performance and outcome in organisations of Tanzania. Since the p-value for this variable was found as 0.00 , it signifies that the correlation between the variables is significant at 0.01 level. Hence, this study demonstrates that when the use of E-Recruitment (E-HRM) is considered, Motivation results are positively related to it.

\section{E-Compensation and Motivation}

The second hypothesis of this study was that ECompensation has a relationship with motivation. The finding of the study intended to establish the extent to which compensation, influences effort, performance and outcome. The p-value is found to be 0.00 , that is significant at 0.01 significant levels. This research delivers the results that the ECompensation (E-HRM) is positively related to motivation.

\section{E-Knowledge Management and Motivation}

The third hypothesis of this study was that EKnowledge management has a relationship with motivation. The finding demarcated examining the extent to which E-Knowledge management influences effort, performance and outcome. This descriptive result of the study found a strong positive relationship between E-Knowledge management (E-HRM) and Effort, Performance and Outcome (Motivation) with the relationship is significant enough in the Tanzanian manufacturing organisations. The t value obtained is 5.699. This value shows that E-Knowledge management does affect motivation.

\section{DISCUSSION}

\section{E-Recruitment and Motivation}

The paper examined the influence of recruitment on motivation focusing on effort, performance and outcome. The results showed that the majority of the respondents had good IT skills. Also, the employees agreed that E-HRM was understood and used by the majority of them and that it helped them. This implies that employees in Tanzanian private organisations were motivated to use EHRM as it leads them to the desired outcomes and well trained with using E-HRM; they also received 
feedback on their progress. This further implies that employees were motivated by E-HRM as information and communication were transparent while choosing a new recruit or during promotions and other job shifts. Clear job descriptions and expectations were available that encouraged and supported to better employees' performance.

This is supported by the inferential results, which showed that recruitment influenced effort, performance and outcome. It is, therefore not surprising that recruitment positively influenced motivation. The significant influence of recruitment can be attributed to the fact that the respondents agreed that E-HRM was easy to use and eased their effort and improved their performance and output. Also, it was found that feedback via knowledge management on employees' performance was received from time to time and it helped improve their performance and better their output. Based on this fact, the inferential results and descriptive results supported each other. This implies that employees of the contacted private organisation clearly understood their progress and importance of E-HRM from an overall business point of view.

Research by Matthews (2006) on the recruitment of law students by the United States Internal Revenue Service described how by moving up the start date of its campus recruitment efforts it was able to fill jobs more easily and with better quality individuals that perform better. Some studies (Li et al., 2006) have the opinion that rewards, including pay increases, promotion, and internal recruitment have a negative effect on motivation which is contrary to this study findings; this may be their study was done in a different country with different environmental factors that affect their employees. Amongst the many advantages of e-recruitment, there is very little literature on its effect on motivation. A survey conducted by Williams (2009) on E-recruitment showed that dwindling recruitment spends focused on web-based recruitment at the expense of traditional methods.
The author also reported that online methods proved far more popular, as two-thirds (66 per cent) of the HR professionals surveyed said that the jobs section of their own company's website was used as a recruitment tool for most jobs which lead to employee motivation, this is in line with these study findings that recruitment influences motivation

\section{E-Compensation and Motivation}

The paper further examined the influence of compensation on employees' motivation. In this case, the study had the hypothesis which stated that compensation influenced motivation, namely effort, performance and outcome. The descriptive results revealed that majority of the respondents' compensation was as per industry standards and as per employees' skill, performance and output. This implies that employees ensure to use E-HRM for reporting their work and positively engage themselves in their jobs and the organisation at large. The inferential results justify this. The inferential results revealed that compensation influenced motivation.

It has been argued that compensation systems decrease costs, errors, and the time it takes to implement compensation planning and motivates employees for better performance and outcome (Dulebohn and Marler, 200. Besides, a study by Gherson and Jackson (2001) claimed that time savings from compensation could be significant, with Dell reporting a $65 \%$ reduction in compensation planning time and Raytheon decreasing processing time from 12 to 6 weeks (Workscape, 2010) and it further helped to report the performance accurately for precise compensation purposes, which further motivated employees' for using E-HRM. Besides, a study by Raytheon revealed that the use of compensation systems reduced error rates, resulted in better decision-making, and made compensation planning more visible to employees hence building a strong positive relationship between employees' and 
organisation and helped in employee motivation (Workscape, 2010).

On the other hand, Khan et al. (2012) in their study on the effect of different components of compensation on the motivation of employees which is not in agreement with this study's findings. This may be their study was done in the banking sector whose work setting is more demanding for the employees, and hence their employees may be influenced by other factors. The result showed that employees are not motivated by compensation. Another academic research by Mauldin (2003) found that the use of expert systems in compensation planning (i.e., developing performance contingent incentives) increased decision accuracy, which built employee confidence in organisational management. These findings are in line with this study finding that compensation positively influences motivation.

\section{E-Knowledge Management and Motivation}

The paper also examined the influence of knowledge management on motivation. The descriptive results revealed that the majority of the respondents agreed that the organisation had information transparency. Furthermore, the descriptive results showed that management was available for them in terms of knowledge about their jobs, performance and outputs; and training was provided from time to time to enhance knowledge and skills. This demonstrated that private organisations were adequately providing support to their employees built their confidence towards the organisation and motivated them.

Descriptive results also support the significant influence of knowledge management on motivation. This demonstrated that the organisations supported their employees in terms of clarity of the information to the extent that they felt being engaged and influential in the overall organisations' decision-making process thus further motivating the employees by making them feel valued. The E-HRM provided a close working relationship and better opportunity to the organisation for their employees so that there is always a sense of connection visible.

The findings are supported by several studies like Wilder (1999) emphasises the increased importance of E-HRM for business decision-making by ensuring employees feel involved and motivated in organisations. An examination of decision support aspects of electronic commerce appears in Holsapple and Singh (2000), a knowledge management view of electronic business, businesses operate in a knowledge-driven economy and increasingly function as knowledge-based organisations (Holsapple and Whinston, 1987; Drucker, 1993). In contrast, Alter (2006) in his paper Goals and Tactics on the Dark Side of Knowledge Management demonstrates findings of knowledge management that directly reflect unethical motives which affect individual performance and outcome within an organisation; these findings are not in line with this study, this might be because his study was purely conceptual study. These may have a negative effect on overall motivation; however, the topic of motivation was overlooked in their study. Amongst many advantages of e-Knowledge management, there is very little knowledge of its effect on motivation, especially in the African context. There is a lack of literature in this area in general.

In today's day and age, an economy where the value of knowledge as input and output is growing; knowledge is a key ingredient of what is bought and sold (both explicitly and implicitly); knowledge resources are rising in importance relative to traditionally recognised resources. Knowledge management is concerned with making the right knowledge available to the right processors (human or computer) at the right times in the right presentations, which helps the overall motivation of the employee. 


\section{CONCLUSION}

Based on the SmartPLS analysis result, the paper concludes that the use of E-HRM does affect motivation. E-HRM is effective in motivating organisation staff. Olivas-Lujan et al. (2007) state that increasing efficiency is gained if motivation involves IT to support the function of human resource. Strohmeier and Kabst (2009) suggest that the staff is, systematically, motivated in varied. When the administrative process for compensation, recruitment and knowledge management and all other processes become easier by E-HRM, there is increased communication and developed HR service which makes for a good internal relationship, in turn further boosting motivation.

The study also concludes that in practice, E-HRM has a significant influence on motivation and that employees will be more positive towards E-HRM use if they see positive outcomes of E-HRM. It is believed that when an E-HRM application finds a perfect base for motivation, it gradually helps the HR department to take the role of a strategic partner. Communication from central management and HR staff is needed to support the use of EHRM.

The study also concludes that, for an E-HRM to be used in the organisations of Tanzania, broader IT environment should be taken into consideration. This IT environment here refers to the IT experiences of the HR professionals in particular and also of all employees of the organisation. According to the analysis result and discussion, EHRM affects motivation, E-HRM training program and skills need to be provided to every staff so that they can use E-HRM for their and organisational benefit, as it has been proved that the staff is motivated if E-HRM is used.

\section{RECOMMENDATION}

The paper recommends the following: Tanzanian private organisations should ensure that their employees have access to E-HRM. This requires the management to make available the technology required and to communicate the vision of the business. This clear communication can help employees' work towards business goals. Tanzanian private organisations should provide feedback and seek feedback on the performance of E-HRM and its effect. Tanzanian private organisations should systematically match the employees' interests and organisational interests. Treating employees as partners and supporting them to achieve organisational objectives should be a priority.

The methods of this paper are purely qualitative, which limit the ability of this study to provide indepth information on why E-HRM had a significant influence on employees' motivation. The use of qualitative research methodology would not change the quantitative research results; rather, it would provide more information on the quantitative results. However, it is important to conduct a quantitative study in order to explore more information on similar studies done earlier in different countries or with different sectors in a similar economy with different variables. Theory of motivation applied in the study only refers to Vroom, i.e., motivation for effort, motivation for performance and motivation for the outcome while other theories of motivation may find different findings. With this fact, it is important to conduct a similar study with different theory in a dissimilar economy in order to contribute to the body of knowledge on the influence of E-HRM to Motivation.

\section{LIMITATIONS}

Several limitations were faced in the conduct of the paper. Data are collected from companies' employees in Tanzania only. The respondents' awareness about the topic under study posts restrictions which affect the accuracy of the answers on the questions asked. Secondly, the technology faces rapid and dynamic growth which 
makes study findings relevant only to a certain period.

\section{REFERENCES}

Alter, S. (2006, January). Goals and tactics on the dark side of knowledge management. In Proceedings of the 39th Annual Hawaii International Conference on System Sciences (HICSS'06) (Vol. 7, pp. 144a-144a). IEEE.

Anderson, R. W. (1997). The Future of Human resource: Forging Ahead or Falling Behind, Personnel Management. McGraw-Hill International Editions.

Armstrong, M. (1987). Human resource management: a case of the emperor's new clothes? Personnel Management.

Babbie, E. (1998). The Practice of Social Research (8th Ed.). Belmont, CA: Wadsworth

Bhattacherjee, A. (2012). Social Science Research: Principles, Methods, and Practices, USF Tampa Bay Open Access Textbooks, Tampa, FL.

Bizer, R. H., \& Rainer, E. (2005). Impact of Semantic web on the job recruitment Process, Wirtschaftsinformatik Physica-Verlag HD, Heidelberg.

Blumberg, B., Cooper, D. R., \& Schindler, P. S. (2011). Business research methods. London: McGraw-Hill Higher Education.

Bowling, A. (1997). Research Methods in Health, Buckingham: Open University Press.

Brink, S., \& McDonnell, S. (2003). eCompensation. The e-merging technologies series, 18, 1-4.

Bulmash, J. (2013). Human Resource Management and Technology. In Canadian Human Resources Management (pp. 49-78). Whitby, CA: McGraw-Hill Ryerson.
Campbell, B. A., Coff, R., \& Kryscynski, D. (2010). Re-thinking sustained competitive advantage from human capital. Academy of Management Review, 37,376-395.

Cappelli, P. \& Neumark, D. (2001). Do highperformance work practices improve establishment-level outcomes? Industrial and Labor Relations Review, 54 (4), 737-775.

Conner, J., \& Ulrich, D. (1996). Human Resource Roles: Creating Value, Not Rhetoric. Human Resource Planning, 19, 38-49.

Crook, T. R., Todd, S. Y., Combs, J. G., Woehr, D. J., \& Ketchen, D. J. Jr. (2011). Does human capital matter? A meta-analysis of the relationship between human capital and firm performance. Journal of Applied Psychology, 96(3), 443-456.

Davenport, T., \& Prusak, L. (1998). Working Knowledge. Boston, MA: Harvard University Press.

Davis, F. D. (1989). Perceived usefulness, perceived ease of use, and user acceptance of information technology. MIS Quarterly, 319340 .

Delaney, J. T., \& Huselid, M. A. (1996). The impact of human resource management practices on perceptions of organizational performance. Academy of Management Journal,39: 949-969.

Drucker, P. F. (1993). The rise of the knowledge society. Wilson Quarterly, 17(2), 52-70.

Dulebohn, J. H. \& Marler, J. H. (2005). ECompensation: The Potential to Transform Practice?. The Brave New World of e-HR: Human Resource Management in the Digital AgeSan Francisco: John Wiley and Sons.

Dulebohn, J. H., \& Marler, J. H. (2005). ECompensation: The potential to transform 
practice. In H. G. Gueutal, \& D. L. Stone (Eds.). The brave new world of e HR: Human resources management in the digital age (166-189). San Francisco: Jossey Bass.

Frey, B. (1997). On the relationship between extrinsic and intrinsic work motivation. International Journal of Industrial Organizations, 15 (4), 427-439.

Gherson, D., \& Jackson, A. P. (2001). Web-based compensation planning. In A. J. Walker (Ed.), Web-based human resources (p. 83-95). New York, NY: McGraw-Hill.

Hafez, M. A. (2011). Maintenance of Human resource (1st Edition). Dar Al Fajr for Publication and Distribution.

Hair, J. F., Black, W. C. Babin, B. J. \& Anderson, R. E. (2010). Multivariate Data Analysis. Upper Saddle River, NJ: Prentice-Hall.

Ho, M., Wilson, M., \& Chen, S. (2010). HRM in New Zealand biotechnology SMEs: emergence of employment systems through entrepreneurship. International Journal of Human Resource Management, 313-336.

Holsapple, C. \& Whinston, A. (1987). Knowledgebased organizations. The Information Society, 5(2), 77-90.

Holsapple, C. W., \& Singh, M. (2000). Toward a Unified View of Electronic Commerce, Electronic Business, and Collaborative Commerce: A Knowledge Management Approach. Knowledge and Process Management. 7(3):151-164.

Holsapple, C.W., \& Joshi, K. D. (2001). Organizational knowledge resources. Decision Support Systems, 31(1), 39- 54.

Howitt, D., \& Cramer, D. (2003). First steps in research and statistics. London: Routledge
Igalens, J., \& Roussel, P. (1999). A study of the relationships between compensation package, work motivation and job satisfaction. Journal of Organizational Behavior, 20, 1003-1025.

International Records Management Trust. (2007). Tanzania case study: fostering trust and integrity in public sector information systems in the ICT environment. London: IRMT, http://www.irmt.org/documents/building_integr ity/case_studies/IRMT_Case_Study_Tanzania. pdf.

Jansen, J. J. P., Bosch, F. A. J. V. D., \& Volberda, H. W., (2005). Managing potential and realized absorptive capacity: how do organizational antecedents' matter? Acad. Manag. J. 48, 9991015.

Keating, M. \& Harrington, D. (2002). The challenges of implementing quality in the Irish hotel industry: a review. Managing Service Quality, 303-15.

Khan, I., Ghauri, T. A., \& Akram, K., (2012). Relationship between Job Satisfaction and HR Practices, an Empirical Research of Different Sectors of University Teachers in Pakistan. International Journal of Learning and Development. 2 (3).

Khatoon, S., (2012). Adoption Of E-HRM In Healthcare Services: An Empirical Study. Aligarh Muslim University.

Khatoon, T., Amin, M. R., \& Hossain, M. (2013). Strategic human resource management (SHR) practices and its effect on financial performance: Evidence from some selected scheduled private commercial banks in Bangladesh. International Journal of Economics, Finance and Management Sciences, 1(3).

Kianto, A., Vanhala, M. \& Heilmann, P. (2016). The impact of knowledge management on job 
East African Journal of Business and Economics, Volume 2, Issue 1, 2020

Article DOI: https://doi.org/10.37284/eajbe.2.1.241

satisfaction. Journal of Knowledge Management, 621-636.

Kline, R. B. (2010). Principles and Practice for Structural Equation Modelling (3rd Eds). New York, NY: Guildford Press.

Krietner, R. \& Kinicki, A. (1998). Leadership organisation behaviour. Mass: Hoffman Press

Lawler, E. E. \& Mohran, S. A. (2003). HR as a strategic partner: What does it take to make it happen? Human Resource Planning, 26, 15-29.

Lepak D. \& Snell S. (1998). Virtual, HR: Strategic human resource management in the $21^{\text {st }}$ century, Human Resource Management Review, 8 (3), 215-234.

Li, Y., Zhao, Y., \& Liu, Y. (2006). The relationship between HRM, technology innovation and performance in China. International Journal of Manpower, 27(7), 679-697.

Liawa, S. S., \& Huang, H. M. (2003). An investigation of user attitudes toward search engines as an information retrieval tool. Computers in Human Behavior, 19(2003), 751765.

Martin, G. (2005). Technology and People Management, the Opportunity and the Challenge. London, UK: Chartered Institute of Personnel and Development.

Mathis, R. L., \& Jackson, J. H., (2010). Human resource management. South-Western College Pub.

Matolo, R. S., Iravo, M., \& Waititu, G. A. (2019). Study on Relationship between Recruitment and Selection and Employee Performance in Technical Training Institutes in Kenya. International Journal of Scientific Research and Management,7(03).
Matthews, J. A. (2006). Dragon multinationals: new players in the 21st century globalization. Asia Pacific Journal of Management, 23, 5-27.

Mauldin, E. G. (2003). An experimental examination of information technology and compensation structure complementarities in an expert system context. Journal of Information Systems Research. 17, 19-41.

Mencken, F.C. \& Winfield, I. (1988). In Search of the "Right Stuff": The Advantages and Disadvantages of Informal and Formal Recruiting Practices in External Labor Markets. The American Journal of Economics and Sociology, 57(2).

Mertens, D. M. (2014). Mixed methods and wicked problems. Journal of Mixed Methods Research, 9, 3-6.

Mutula, S. (2010). A proposed model for evaluating the success of WebCT and course content management systems approach. Computers and Education, 60(1), 1795-1805.

Nkohkwo, Q. N. A., \& Islam, M. S. (2013). Challenges to the Successful Implementation of e-Government Initiatives in Sub-Saharan Africa: A Literature Review. Electronic Journal of e-government, 11(1), 253-253.

Orodho, J. A. \& Kombo, D. K. (2003). Designing and Evaluating Research. Nairobi. Kenyatta University Institute of Open Learning.

Parry, E. (2011). An examination of E-HRM as a means to increase the value of the HR function. The International Journal of Human Resource Management, 22(5), 1146-1162.

Poisat, P., \& Mey, M. R. (2017). Electronic human resource management: Enhancing or entrancing? SA Journal of Human Resource Management, 15(1), 1-9. 
Ramlall, S. (2004). A Review of Employee Motivation Theories and Their Implications for Employee Retention Within Organisations. Journal of American Academy of Business, Cambridge, 52-63.

Robbins, S. (1993). Organisational Behaviour: Concepts, Controversies, and Applications (6thedition). New Jersey: Prentice-Hall.

Ruel, H., Bondarouk, T., \& Looise, J. (2004). EHRM: Innovation or irritation. An explorative empirical study in five large companies on webbased HRM. Management Review, 15 (3), 364381.

Ruta, C. (2005). The application of change management theory to HR portal implementation in subsidiaries of multinational corporations. Human Resource Management, 44 (1), 35-53.

Saunders, M., Lewis, P., \& Thornhill, A. (2003). Research method for business students (3rd edition). New York: Prentice Hall.

Saunders, M., Lewis, P. \& Thornhill, A. (2009). Research methods for business students. $5^{\text {th }}$ ed. Harlow: Pearson Education Limited.

Shultz, R. L., \& Slevin, D. P. (1975). Implementation and organizational validity: An empirical investigation in implementing operations research and management science. New York: American Elsevier Publishing.

Stewart, T. (1997). Intellectual Capital: The New Wealth of Organizations. London, UK: Nicholas Brealey.

Stone, D. N., Deci, E. L. \& Ryan, M. R. (2009). Beyond talk: creating autonomous motivation through self-determination theory. Journal of General Management, 75-91.
Strohmeier, S. (2007). Research in E-HRM: Review and implications. Human Resource Management Review, 17: 19-37.

Strohmeier, S., \& Kabst, R. (2009). Organizational Adoption Of E-HRM In Europe: An Empirical Explanation of Major Adoption Factors. Journal of Managerial psychology, 24(6). 482.

Sveiby, K. (1997). The New Organizational Wealth: Managing and Measuring Knowledgebased Assets. San Francisco, CA: BerrettKoehler Publishers.

Teo, T. S. H., Lim, V. K. G., \& Lai, R. Y. C. (1999). Intrinsic and Extrinsic Motivation in Internet Usage. 25-37.

Ulrich, D. (1996). Human resource champions: The next agenda for adding value and delivering results. Harvard Business Press.

Venkatesh, D., \& Davis, F. D. (1996). A model of the perceived ease of use development and test. Decision Sciences, 27(3), 451-481.

Voermans, M., \& Veldhoven, M. V. (2007). Attitude towards E-HRM: An empirical study at Philips. Personnel Review, 36(6), 887-902.

Vroom, V. (1964). Work and Motivation. New York: Wiley.

Walinda, S. R. (2013). Development of electronic human resource management for public institutions in Tanzania: a case of Tanzania civil aviation authority. Open University of Tanzania.

Watson-Wyatt, W. (2002). Human capital as a lead indicator of shareholder value: 2001/2002 survey report. Watson Wyatt Worldwide.

Wilder, C. (1999). E-business work status. Information week. 53-54.

William, H., (2009). E-recruitment: Rethinking recruitment. Personnel today survey. 
Wilson, P. (2009). True North. No Direction. HR Monthly. 20-3.

Workscape, H. (2010). Automated compensation planning process enables more strategic decision making at Raytheon. Retrieved May 11, 2014 at http://www.workscape.com/ /media/Files/Clie nt_Case_Studies/WorkscapeRaytheonCaseStud y.ashx

Yanow, D., \& Schwartz-Shea, P., (2015). Interpretation and Method: Empirical Research Methods and the Interpretive Turn. London, UK: Routledge.

Yong, A. G., \& Pearce, S. (2013). A beginner's guide to factor analysis: Focusing on exploratory factor analysis. Tutorials in Quantitative Methods for Psychology, 9(2), 7994.

Yusliza, M. Y., \& Hasliza, A. H. (2009). Examination of the Psychometric Characteristics of the Multidimensional Scale of HR Roles. December, Kuala Lumpur, Malaysia. In Proc. 5th Int. Conf. Glob. Aca. Bus. Econ. Res (pp. 28-30). 